\title{
Use of the Mitsunobu Reaction in the Synthesis of Orthogonally Protected a,b-Diaminopropionic Acids
}

\author{
Fintan Kelleher \\ Technological University Dublin, fintan.kelleher@tudublin.ie \\ Keith Ó Proinsias \\ Technological University Dublin
}

Follow this and additional works at: https://arrow.tudublin.ie/ittsciart

Part of the Organic Chemistry Commons

\section{Recommended Citation}

Kelleher, F. and O'Proinsias, K. Use of the Mitsunobu reaction in the synthesis of orthogonally protected a,b-diaminopropionic acids. Tetrahedron Letters, 48(28):4879-4882. DOI:10.1016/j.tetlet.2007.05.064

This Article is brought to you for free and open access by the School of Science and Computing at ARROW@TU Dublin. It has been accepted for inclusion in Articles by an authorized administrator of ARROW@TU Dublin. For more information, please contact arrow.admin@tudublin.ie, aisling.coyne@tudublin.ie, gerard.connolly@tudublin.ie. Funder: Irish Government 
Use of the Mitsunobu reaction in the synthesis of orthogonally protected $\alpha, \beta$ diaminopropionic acids.

Fintan Kelleher* and Keith ó Proinsias

National Institute for Cellular Biotechnology, Department of Science, Institute of Technology Tallaght, Dublin 24, Ireland.

Corresponding Author: Dr. Fintan Kelleher

Address: Department of Science,

Institute of Technology Tallaght,

Tallaght,

Dublin 24,

Ireland.

Phone Number: (+353 1) 4042869

Fax Number: $\quad$ (+353 1) 4042700

e-mail address: $\quad$ fintan.kelleher@ittdublin.ie

Graphical abstract :

Use of the Mitsunobu reaction in the synthesis of orthogonally protected $\alpha$, $\beta$-diaminopropionic acids.

Fintan Kelleher* and Keith ó Proinsias

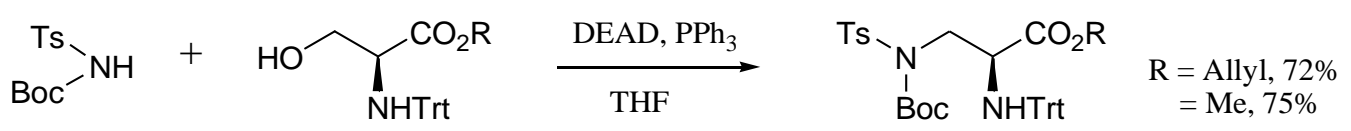

The reaction of $N$-trityl L-serine esters with $N$-substituted sulfonamides (e.g. Boc-NH-Ts) under Mitsunobu conditions gives orthogonally protected $\alpha, \beta$-diaminopropionic acids in good yields. 


\title{
Use of the Mitsunobu reaction in the synthesis of orthogonally protected $\alpha, \beta$ - diaminopropionic acids.
}

\author{
Fintan Kelleher* and Keith ó Proinsias
}

National Institute for Cellular Biotechnology, Department of Science, Institute of Technology Tallaght, Dublin 24, Ireland.

\begin{abstract}
:
Orthogonally protected $\alpha, \beta$-diaminopropionic acids have been synthesised in good yields by the reaction of $N$-trityl L-serine esters with $N$-substituted sulfonamides under Mitsunobu reaction conditions (DEAD, $\left.\mathrm{PPh}_{3}, \mathrm{THF}\right)$. The best isolated yields were obtained when $\mathrm{N}$-Boc $p$-toluenesulfonamide was used as the nitrogen nucleophile precursor in the Mitsunobu reaction. Subsequently, the $N$-trityl group was efficiently replaced with the more stable allyloxycarbonyl (alloc) group.
\end{abstract}

Interest in the properties of $\alpha, \beta$-diamino acids is evidenced by the large number of publications in the area. A recent review has highlighted the wide range of methods for their synthesis and also the myriad of possible biological applications. ${ }^{1}$ A number of recent examples, in particular, demonstrate the different approaches to the preparation of these types of compounds. Lee prepared 2,3-diaminopropionates by ring opening of aziridine-2-carboxylates with azide ions and subsequent reduction of the azido group to an amine, ${ }^{2}$ while Panda used the Mitsunobu reaction ${ }^{3}$ of $\mathrm{HN}_{3}$ on $\mathrm{N}$ protected L-serine-derived Weinreb amides. ${ }^{4}$ The reason for the use of the Weinreb amide derivative was to reduce the acidity of the serine $\alpha$-hydrogen and thus stop the formation of a dehydroalanine (Dha) by a dehydration reaction. Pedatella prepared orthogonally protected 2,3-diamino acids by treatment of the enolate of $\mathrm{N}, \mathrm{N}$ dibenzylated $\beta$-amino esters with di-tert-butyl azodicarboxylate (DBAD). Subsequent removal of the Boc group and cleavage of the hydrazine gave the 2,3-diamino acids. ${ }^{5}$ Nadir prepared 2,3-diamino acids by reaction of $N$-arylsulfonyl aziridines with a chiral isocyanate and subsequent hydrolysis of 2 -imidazolidinones. ${ }^{6}$ 
As part of a program of peptide synthesis, incorporating unusual amino acid residues, we are interested in the synthesis of orthogonally protected $\alpha, \beta$-diaminopropionic acids for solid-phase peptide synthesis. We decided to examine the Mitsunobu reaction of L-serine derivatives with nitrogen-based nucleophiles, other than azide, for their synthesis. Our first choice was sulfonamide based nucleophiles (Ts or Ns) because they have appropriate $\mathrm{pK}_{\mathrm{a}}$ values. In 1989 Weinreb introduced the Ts-NHBoc in the Mitsunobu reaction for the conversion of alcohols into $N$-Boc $p$ toluenesulfonamides in excellent yields. ${ }^{7}$ A survey of the literature shows that the correct choice of nitrogen and/or carboxyl protecting groups is critical to the positive outcome of the Mitsunobu reaction at the hydroxyl group of L-serine derivatives. In many cases the incorrect choice of protecting group leads to elimination reactions giving Dha compounds, or cyclisations to form aziridines. Cherney and Wang showed that protection of the L-serine nitrogen with a trityl group gives excellent yields of Mitsunobu products, using phthalimide as the nitrogen nucleophile, where the carboxyl group was protected as the methyl ester. ${ }^{8}$ The trityl group works in two ways, by sterically preventing cyclisation of the nitrogen to form aziridnes, and secondly, by reducing the acidity of the $\alpha$-hydrogen compared to carbamate protecting groups, thus preventing Dha formation. We prepared $N$-trityl L-serine methyl ester (2) in 75\% yield from L-serine methyl ester (1) using the method of Baldwin (Scheme 1). ${ }^{9}$ Subsequent treatment of $\mathbf{2}$ with the commercially available Weinreb nucleophile Ts-NH-Boc (3), under Mitsunobu reaction conditions (diethyl azodicarboxylate (DEAD), $\mathrm{PPh}_{3}, \mathrm{THF}$ ), gave the orthogonally protected $\alpha, \beta$ diaminopropionic acid (4) in $75 \%$ isolated yield. Due to the propensity for the trityl group to be easily removed, even on treatment with mild acid, we decided to replace this group with the more stable $\mathrm{N}$-allyloxycarbonyl (alloc) protecting group, which also keeps full orthogonality with the other protecting groups present.

Treatment of 4 with 5\% TFA in chloroform and subsequent reaction with allyl chloroformate gave the $\mathrm{N}$-alloc compound $\mathbf{5}$ in an isolated yield of only $30 \%$. All attempts to improve the yield of this two-step process were unsuccessful. Removal of the Boc protecting group on the $\beta$-nitrogen was efficiently achieved (90\% yield) on treatment of $\mathbf{4}$ with a $50 \%$ TFA in chloroform solution to give sulfonamide $\mathbf{6}$, which possesses a free sulfonamide $\mathrm{N}-\mathrm{H}$ for further derivatisation of the $\beta$-nitrogen, if 
required. Thus we have successfully prepared 6 , but in a poor yield of only $27 \%$, from 4. We were pleased to find that if we treated 4 directly with a 50\% TFA in chloroform solution, followed by reaction of the unpurified intermediate amine with allyl chloroformate, we were able to prepare sulfonamide $\mathbf{6}$ in a much improved isolated yield of $74 \%$.

We were interested in extending the scope of this method in three ways, i) by changing the groups on the sulfonamide nucleophilic moiety, ii) by using a different ester of the $N$-trityl L-serine and iii) using di-iso-propyl azodicarboxylate (DIAD) instead of DEAD. Bach reported the use of the Fmoc sulfonamide, Ts-NH-Fmoc (7), in the Mitsunobu reaction of alcohols, where the isolated product showed the concomitant loss of the Fmoc group, though the reasons for this result were not discussed. ${ }^{10}$ This reaction was of interest to us at it would lead directly to a compound with a free sulfonamide N-H. Thus Fmoc sulfonamide 7 was prepared in good yield, by an adaptation (using fluorenylmethyl alcohol) of Weinreb's synthesis of $\mathbf{3}{ }^{7}$ and was subjected to reaction with protected serine 4, under similar Mitsunobu conditions to those used for the Boc derivative, however none of the desired product was obtained. The two starting materials were re-isolated from the reaction intact. It is known that Fukuyama has performed extensive studies on the use of nitrobenzenesulfonamides in the Mitsunobu reaction, ${ }^{11}$ where the presence of the nitro group(s) lowers the $\mathrm{pK}_{\mathrm{a}}$ values of the sulfonamides. We prepared a number of nosyl sulfonamides (8-11, Figure 1) ${ }^{12}$ in order to examine their usefulness in the Mitsunobu reaction of suitably protected serines. All reactions of these sulfonamides with $N$-trityl L-serine methyl ester 4, under the Mitsunobu conditions used previously, using either DEAD or DIAD, were unsuccessful, with only starting materials being isolated in each case.

We next studied the effect of using a different carboxylic ester L-serine protecting group instead of the methyl ester. We chose the allyl ester and the required Mitsunobu reaction precursor, $N$-trityl L-serine allyl ester (12), was prepared by standard conditions $^{13}$ (Scheme 2). Thus $N$-trityl L-serine was prepared in $48 \%$ yield starting from serine by treatment with trityl chloride and trichloromethylsilane in DCM. Subsequent allylation of the cesium salt of $N$-trityl L-serine, in DMF, gave the allyl ester 12 in $90 \%$ isolated yield. 
Reaction of 12 with Ts-NH-Boc (3), under Mitsunobu reaction conditions (DEAD, $\left.\mathrm{PPh}_{3}, \mathrm{THF}\right)$, again gave an orthogonally protected $\alpha$, $\beta$-diaminopropionic acid (13), on this occasion in $72 \%$ isolated yield. In this case when the $N$-trityl group was replaced with the $N$-alloc group followed by removal of the Boc group on the sulfonamide, in the two-step method, the sulfonamide 15 was isolated, via 14, in a very poor yield of 19\%. Gratifyingly, when the trityl and Boc protecting groups were removed simultaneously, and the intermediate amine was reacted with allyl chloroformate under basic conditions, $\mathbf{1 5}$ was obtained in a vastly improved yield of $83 \%$. As before, we examined the use of the nosyl sulfonamides 8-11 in the Mitsunobu reaction with 12. In this case the only successful reaction was with the p-methoxybenzyl (PMB) substituted $o$-nitrobenzenesulfonamide 11, where the desired product 16 was obtained in a $51 \%$ yield. In all other reactions only the starting materials were re-isolated. As before, $\mathbf{1 6}$ was efficiently converted to the $N$-alloc protected compound $\mathbf{1 7}$ (Scheme 2).

In conclusion we have prepared orthogonally protected $\alpha, \beta$-diaminopropionic acids in good yields from protected L-serines using the Mitsunobu reaction of sulfonamidederived nitrogen nucleophiles. Currently we are studying the chemistry of these compounds, e.g. the clean removal of the individual protecting groups, and their incorporation into peptide structures using solid-phase peptide synthesis. We are also examining further functionalisation reactions of N-H sulfonamide compounds 6 and 15. The results of these studies will be reported in due course.

Typical procedure for Mitsunobu reaction, exemplified by the synthesis of 13. To a solution of $N$-(tert-butoxycarbonyl)-p-toluenesulfonamide $3(0.16 \mathrm{~g}, 0.68 \mathrm{mmol})$ in dry THF ( $3 \mathrm{ml})$ was added $\mathrm{PPh}_{3}(0.34 \mathrm{~g}, 1.4 \mathrm{mmol})$, followed by the addition of $\mathbf{1 2}$ $(0.16 \mathrm{~g}, 0.46 \mathrm{mmol})$ and DEAD $(0.19 \mathrm{~g}, 1.2 \mathrm{mmol})$. The resulting mixture was allowed to stir at room temperature, under a nitrogen atmosphere, for $10 \mathrm{~h}$. The solvent was removed in vacuo giving an orange oil which was purified by flash column chromatography on silica gel, in petroleum ether:ethyl acetate $(10: 1)$, to give a white solid $(0.30 \mathrm{~g}, 72 \%)$. Mp: $143-145{ }^{\circ} \mathrm{C} . \mathrm{R}_{\mathrm{f}}$ : 0.80 , petroleum ether/ethyl acetate (2/1). IR ( $\mathrm{KBr}) \mathrm{cm}^{-1}: 3433,3066,2924,1734,1595,1234,1139 .{ }^{1} \mathrm{H}$ NMR $\left(\mathrm{CDCl}_{3}\right.$, 
$300.4 \mathrm{MHz}) \delta \mathrm{ppm}, 7.77$ (d, 2H, $J=12.3 \mathrm{~Hz}$, ortho tosyl), 7.54 (d, 6H, $J=12.9 \mathrm{~Hz}$, ortho trityl), 7.27-7.23 (d, $2 \mathrm{H}, J=12.3 \mathrm{~Hz}$, meta tosyl and $\mathrm{m}, 9 \mathrm{H}$, para and meta trityl), $5.56(\mathrm{~m}, 1 \mathrm{H}$, vinyl $\mathrm{CH}), 5.11\left(\mathrm{~m}, 2 \mathrm{H}\right.$, vinyl $\left.\mathrm{CH}_{2}\right), 4.24(\mathrm{dd}, 1 \mathrm{H}, J=8.4$ and 8.6 $\mathrm{Hz}$, allyl $\left.\mathrm{CH}_{2}\right), 4.11\left(\mathrm{~m}, 1 \mathrm{H}\right.$, allyl $\left.\mathrm{CH}_{2}\right), 3.92(\mathrm{dd}, 1 \mathrm{H}, J=5.3$ and $6.0 \mathrm{~Hz}, \alpha-\mathrm{CH}), 3.80$ $\left(\mathrm{m}, 2 \mathrm{H}, \beta-\mathrm{CH}_{2}\right), 2.86(\mathrm{~d}, 1 \mathrm{H}, J=11.1 \mathrm{~Hz}, \mathrm{NH}), 2.37\left(\mathrm{~s}, 3 \mathrm{H}\right.$, tosyl $\left.\mathrm{CH}_{3}\right), 1.25(\mathrm{~s}, 9 \mathrm{H}, t-$ butyl). ${ }^{13} \mathrm{C} \mathrm{NMR}\left(\mathrm{CDCl}_{3}, 75.45 \mathrm{MHz}\right) \delta \mathrm{ppm}, 172.6$ (ester $\left.\mathrm{C}=\mathrm{O}\right), 150.8$ (Boc $\mathrm{C}=\mathrm{O}$ ), 145.7 (ipso trityl), 144.1 (para tosyl), 137.4 (ipso tosyl), 131.8 (vinyl $\mathrm{CH}$ ), 129.2 (meta trityl), 128.8 (meta tosyl), 128.1 (ortho trityl), 127.8 (ortho tosyl), 126.4 (para trityl), 118.3 (vinyl $\left.\mathrm{CH}_{2}\right), 84.4\left(\mathrm{C}_{\mathrm{q}} t\right.$-butyl), 70.9 (allyl $\left.\mathrm{CH}_{2}\right), 65.9\left(\mathrm{C}(\mathrm{Ph})_{3}\right), 56.0(\alpha$ $\mathrm{CH}), 50.4\left(\beta-\mathrm{CH}_{2}\right), 27.8\left(\mathrm{CH}_{3} t\right.$-butyl), $21.6\left(\mathrm{CH}_{3}\right.$ tosyl). Mass Spec: Expected $[\mathrm{M}+1]$ 641.2685, observed [M+1] 641.2690.

\section{Acknowledgements}

We are grateful to Cycle III of the Higher Education Authority's Program for Research in Third Level Institutions (PRTLI) under the Irish Government's National Development Plan (2000-2006) for funding for K ó’P.

\section{References and Notes}

1. Viso, A.; Fernandez de la Partilla, R.; Garcia, A.; Flores, A. Chem. Rev. 2005, 105, 3167 .

2. Kim, Y; Ha, H-J; Han, K.; Ko, S.; Yun, H.; Yoon, H.; Kim, M; Lee, W. Tetrahedron Lett. 2005, 46, 4407.

3. Mitsunobu, O. Synthesis 1981, 1.

4. Panda, G.; Rao, N. V. Synlett 2004, 714.

5. Capone, S.; Guaragna, A.; Palumbo, G.; Pedatella, S. Tetrahedron 2005, 61,6575 .

6. Nadir, U.; Krishna, R.; Singh, A. Tetrahedron Lett. 2005, 46, 479.

7. Henry, J.; Marcin, L.; McIntosh, M.; Scola, P.; Harris Jr, P. D.; Weinreb, S. Tetrahedron Lett. 1989, 30, 5709.

8. Cherney, R.; Wang, L. J. Org. Chem. 1996, 61, 2544.

9. Baldwin, J.; Spivey, A.; Schofield, C.; Sweeney, J. Tetrahedron 1993, 49, 6309.

10. Bach, T.; Kather, K. J. Org. Chem. 1996, 61, 7642. 
11. Kan, T.; Fukuyama, T. Chem. Commun. 2004, 353.

12. Compounds $\mathbf{8}$ and $\mathbf{1 0}$ were prepared according to Kurosawa, W; Kan, T; Fukuyama, T.; Cheung, M.; Kan, T. Synlett. 1999, 1301, and compound 9 was prepared by an adaptation of this method. Compounds 11a and 11b was prepared according to the method of Kurosawa, W; Kan, T; Fukuyama, T. Org. Synth. 2002, 79, 186. Note: Analytical data for 9: Mp: 121-122 ${ }^{\circ} \mathrm{C} . \mathrm{R}_{\mathrm{f}}$ : 0.69, methanol/chloroform (1/2). IR (KBr) $\mathrm{cm}^{-1}: 3308$, 3021, 1540, 1364, 1158. ${ }^{1} \mathrm{H}$ NMR $\left(\mathrm{CDCl}_{3}, 300.4 \mathrm{MHz}\right) \delta \mathrm{ppm}, 8.05(\mathrm{~d}$, $2 \mathrm{H}, J=8.9 \mathrm{~Hz}$, ortho nosyl), 7.83 (d, 2H, J = 8.9 Hz, meta nosyl), 7.54 (d, $2 \mathrm{H}, J=8.2 \mathrm{~Hz}$, ortho tosyl), 7.03 (d, 2H, $J=7.8 \mathrm{~Hz}$, meta tosyl), 2.31 (s, $3 \mathrm{H}$, tosyl). ${ }^{13} \mathrm{C} \mathrm{NMR}\left(\mathrm{CDCl}_{3}, 75.45 \mathrm{MHz}\right) \delta \mathrm{ppm}, 149.1$ (para nosyl), 143.3 (ipso nosyl), 141.8 (para tosyl), 139.3 (ipso tosyl), 129.5 (meta tosyl), 128.6 (ortho nosyl), 127.9 (ortho tosyl), 123.1 (meta nosyl), 21.4 ($\mathrm{CH}_{3}$, tosyl).

13. Mustapa, M. F. M.; Harris, R.; Bulic-Subanovic, N.; Elliott, S.; Bregant, S.; Groussier, M.; Mould, J.; Schultz, D.; Chubb, N.; Gaffney, P.; Driscoll, P.; Tabor, A. J. Org. Chem. 2003, 68, 8185.

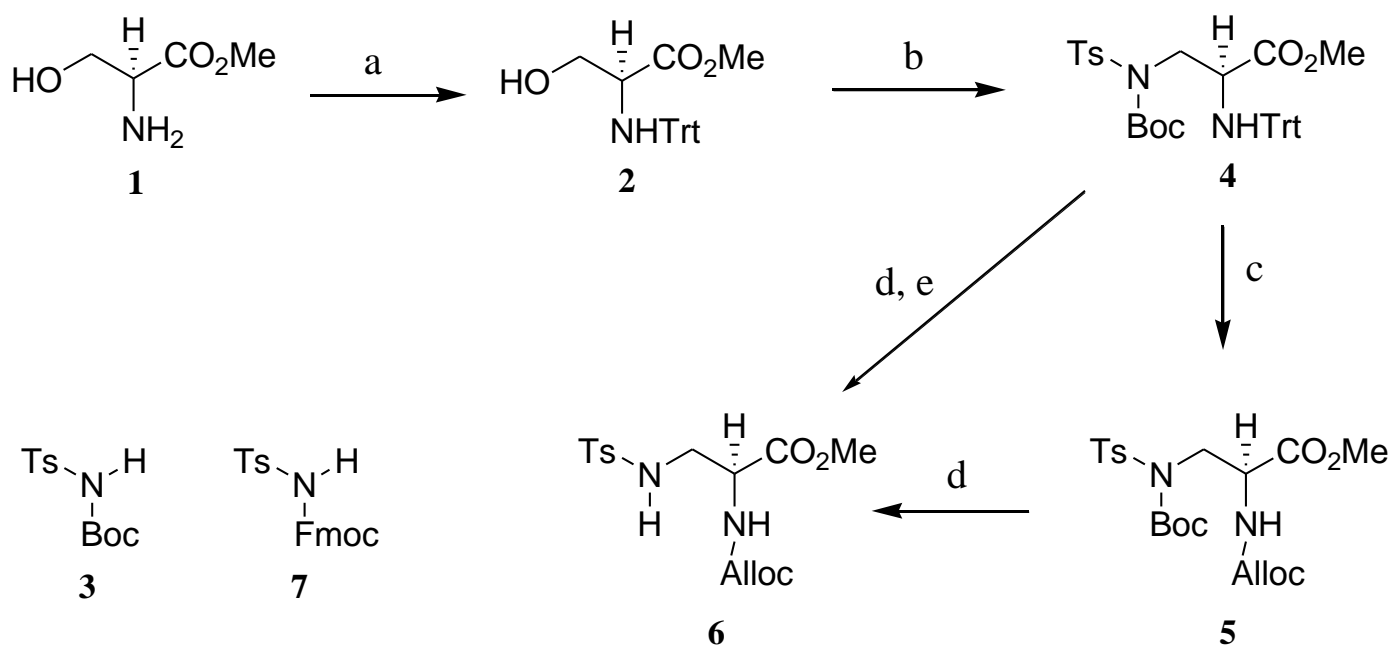

Scheme 1: Reagents and conditions; (a) Trityl chloride, $\mathrm{Et}_{3} \mathrm{~N}, \mathrm{DCM}, \mathrm{rt}, 75 \%$; (b) 3, DEAD, $\mathrm{PPh}_{3}, \mathrm{THF}$, rt, $75 \%$; (c) i) $5 \%$ TFA in $\mathrm{CHCl}_{3}$, ii) allyl chloroformate, $\mathrm{NaHCO}_{3}, \mathrm{H}_{2} \mathrm{O}, 1$,4-dioxane, rt, 30\%; (d) $50 \%$ TFA in $\mathrm{CHCl}_{3}$, rt; (e) $\mathrm{NaHCO}_{3}, \mathrm{H}_{2} \mathrm{O}$, allyl chloroformate, rt. 
<smiles></smiles>

8<smiles>O=[N+]([O-])c1ccc(S(=O)(=O)N[123I])cc1</smiles>

9<smiles>CNS(=O)(=O)c1ccccc1[N+](=O)[O-]</smiles>

Boc

10<smiles>CCCCN[SH+]([O-])(O)c1ccccc1[N+](=O)[O-]</smiles>

11

Figure 1: Nosyl sulfonamide derivatives prepared.,

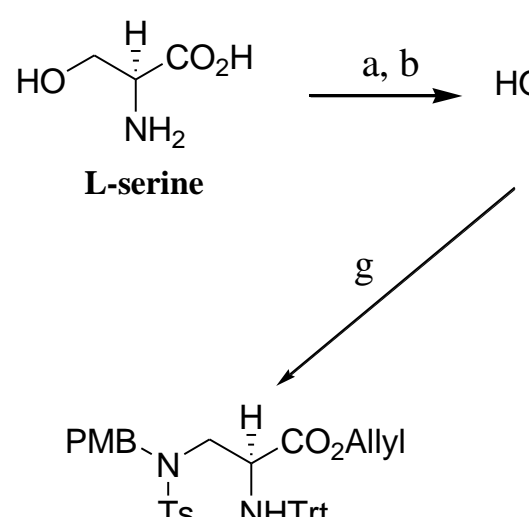

16

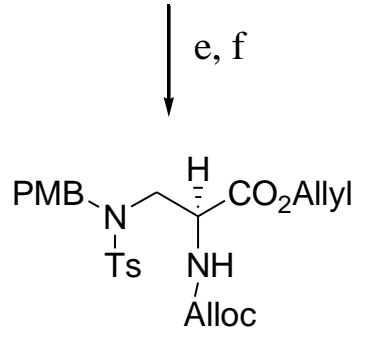

17<smiles>CCCC(CO)C(=O)OCC</smiles>

12
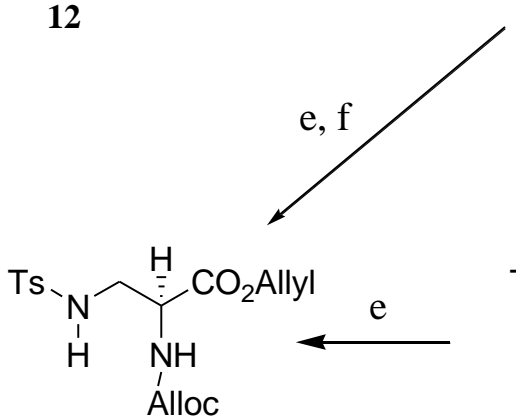

15<smiles>CCCNC(CN([P])C(=O)OCc1ccccc1)C(=O)OC</smiles>

13

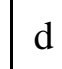

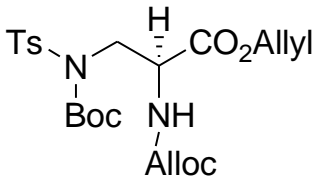

Scheme 2: Reagents and conditions; (a) Trityl chloride, trichloromethylsilane, $\mathrm{Et}_{3} \mathrm{~N}, \mathrm{DCM}, \mathrm{rt}, 48 \%$; (b) i) $\mathrm{Cs}_{2} \mathrm{CO}_{3}, \mathrm{MeOH}$, ii) Allyl bromide, DMF, rt, 90\%; (c) 3, DEAD, $\mathrm{PPh}_{3}, \mathrm{THF}, \mathrm{rt}, 72 \%$; (d) i) $5 \%$ TFA in $\mathrm{CHCl}_{3}$, ii) allyl chloroformate, $\mathrm{NaHCO}_{3}, \mathrm{H}_{2} \mathrm{O}, 1$,4-dioxane, rt, $19 \%$ from 13; (e) $50 \%$ TFA in $\mathrm{CHCl}_{3}$, rt; (f) Allyl chloroformate, $\mathrm{NaHCO}_{3}, \mathrm{H}_{2} \mathrm{O}$, rt; (g) 11, DEAD, $\mathrm{PPh}_{3}$, THF, rt, $51 \%$. 